\title{
Analisis Tingkat Penerimaan Pengguna terhadap Fitur-fitur Facebook untuk e-Commerce
}

\author{
Nabila Payapo ${ }^{1}$, Lana Sularto ${ }^{2}$ \\ ${ }^{1}$ Jurusan Teknik Informatika Sekolah Tinggi Ilmu Komputer (STIKOM) Ambon \\ Jln. A.Y. Patty No. 98, Kel. Honipopu, Kec. Sirimau, Ambon, Maluku, Indonesia \\ ${ }^{1}$ payapo_nabila@yahoo.co.id \\ ${ }^{2}$ Universitas Gunadarma \\ Jln. Margonda Raya No. 100, Pondok Cina, Kec. Beji, Kota Depok, Jawa Barat, Indonesia \\ ${ }^{2}$ lana@staff.gunadarma.ac.id
}

\begin{abstract}
Intisari- Tujuan penelitian ini adalah untuk mengetahui dan menjelaskan mengenai tanggapan pengguna Facebook untuk kegiatan ecommerce dari empat sisi yaitu persepsi kemudahan penggunaan, persepsi sikap penggunaan, permasalahan perilaku untuk menggunakan, dan kondisi nyata penggunaan sistem Facebook untuk kegiatan e-commerce di kota Ambon. Populasi dalam penelitian ini adalah warga kota Ambon dan ditentukan 30 orang sebagai sampel penelitian. Dari hasil analisis diperoleh nilai rata-rata ketercapaian skore untuk empat sisi yang diuji adalah masing-masing sebesar $83 \%, 81 \%, 79 \%$, dan $76 \%$, sehingga dapat disimpulkan bahwa persepsi kemudahan penggunaan memiliki pengaruh signifikan positif terhadap sikap penggunaan, kemudian sikap penggunaan memiliki pengaruh signifikan positif terhadap perilaku untuk menggunakan, dan perilaku untuk mengggunakan memiliki pengaruh signifikan positif terhadap kondisi nyata penggunaan sistem Facebook.
\end{abstract}

Kata kunci- Penerimaan, kemudahan, penggunaan, sikap, perilaku, menggunakan, sistem.

Abstract - The purpose of this study is to find out and explain Facebook users' responses to e-commerce activities from four sides, namely perceived ease of use, perceived attitude of use, behavioral problems to use, and the real conditions of using the Facebook system for e-commerce activities in Ambon city. The population in this study were Ambon city residents and 30 people were selected as the study sample. From the results of the analysis obtained the average value of achievement scores for the four sides tested were 83\%, $81 \%, 79 \%$, and $76 \%$, so it can be concluded that the perception of ease of use has a significant positive effect on the attitude of use, then attitudes usage has a significant positive effect on behavior to use, and behavior to use has a significant positive effect on the real conditions of the Facebook system usage.

Keywords - Acceptance, ease, use, attitude, behavior, use, system.

\section{Pendahuluan}

Penggunaan teknologi komunikasi dan informasi yang populer bagi pebisnis saat ini adalah Internet dalam menghadapi persaingan bisnisnya. Internet kini sudah umum digunakan untuk memasarkan suatu produk. Strategi bisnis melalui Internet menjadi populer saat ini karena meningkatnya pengguna Internet di dunia dan kemudahaan yang diperoleh pebisnis dalam memasarkan dan mengembangkan bisnisnya. Salah satu strategi pemasaran dengan menggunakan sarana Internet adalah melalui e-commerce. E-marketing adalah suatu usaha yang dilakukan untuk melakukan pemasaran produk atau jasa dengan menggunakan media Internet, yang terdiri dari kerja perusahaan untuk mengkomunikasikan sesuatu, mempromosikan, dan menjual barang dan jasa melalui Internet. e-Commerce adalah sistem penjualan yang berkembang setelah ditemukan Internet. Sistem pemasaran atau penjualan seperti ini dapat menjangkau seluruh dunia pada saat yang bersamaan tanpa harus mendirikan kantor cabang di semua negara. Selain itu juga dapat dilakukan 24 jam tanpa berhenti. Dengan hanya melalui unit komputer yang terhubung ke Internet, perusahaan dapat memasarkan produk-produknya [1].
Pemasaran pada awal abad ke-21 sedikit demi sedikit mulai mengalami perubahan, peristiwa tersebut ditunjang dengan kegiatan pengembangan di sektor teknologi. Cara berkomunikasi dalam pemasaran juga mendapatkan modernisasi atau perbaikan, berawal dari komunikasi pemasaran secara person-to-person (orang-ke-orang) hingga terjadinya word-of-mouth saat ini diarahkan pada computer mediated communication dengan new wave technology, yaitu komunikasi berbasiskan pada teknologi yang memberikan kemudahan kepada penggunannya untuk mengekspresikan diri dan berkolaborasi dengan pengguna lainnya. Filosofi ini merupakan dasar dari terbentuknya media sosial. Media sosial merupakan seperangkat aplikasi berbasiskan pada jaringan internet yang didasari oleh Web 2.0, program tersebut yang ditemukan oleh Tim O'reilly pada tahun 2003. Web 2.0 merupakan suatu platform dasar terbentuknya media sosial, platform ini menyediakan kemudahan bagi penggunanya untuk berkolaborasi secara online dan berbagi (sharing). Media sosial, seperti Facebook, Instagram, dan Twitter, saat ini digunakan untuk menyebarluaskan informasi secara cepat, viral, dan menyebar kepada pengguna Internet dalam jumlah yang besar. Media sosial adalah sebuah fenomena baru yang telah mengubah cara lingkungan bisnis beroperasi. Melalui media 
sosial, bisnis mendapatkan akses berkaitan dengan sumber daya yang dinyatakan tidak tersedia bagi pemilik bisnis. Hal ini juga membantu perusahaan untuk meningkatkan kelayakan mereka, memupuk kemitraan strategis dan meningkatkan kontak mereka dengan pelanggan dan pemasok. Hal ini menjadi amat penting bagi pemilik bisnis dan pemasaran untuk memahami bagaimana media sosial bekerja sebagai alat komunikasi, pemasaran dan bagaimana mereka secara signifikan dapat mengembangkan bisnis mereka.

Menurut data publish per tanggal 1 April 2019, disebutkan bahwa 92\% penjual menggunakan Facebook dalam transaksi $e$ commerce [2] seperti grafik yang ditunjukkan pada Gambar 1.

Transaksi E-Commerce Melaui Platform Media Sosial

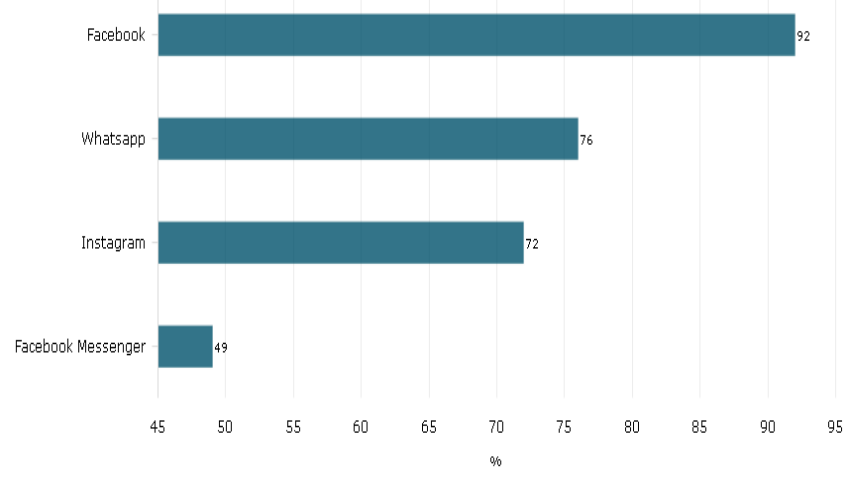

(이웅 DATABOKS.CO.ID

Gambar 1. Transaksi e-Commerce Melalui Platform Media Sosial [2].

Jumlah penduduk Kota Ambon sebanyak 427.934 jiwa yang mencakup mereka yang bertempat tinggal di daerah perkotaan sebanyak 305.984 jiwa atau 92,37 persen dan di daerah pedesaan sebanyak 25270 jiwa atau 7,63 persen. Median umur penduduk Kota Ambon adalah 24,38\%. Angka ini menunjukkan bahwa penduduk Kota Ambon termasuk kategori menengah. Penduduk suatu wilayah dikategorikan penduduk muda bila median umur kurang dari 20 tahun, penduduk menengah jika median umur antara 20 sampai 30 tahun, dan penduduk tua jika median umur lebih dari 30 tahun. Berdasarkan komposisi jenis kelamin, penduduk laki-laki Kota Ambon sebanyak 213.630 jiwa dan perempuan sebanyak 214.304 jiwa [3]. Setiap warga Ambon pasti mempunyai alat komunikasi mobile seperti handphone. Hal ini terlihat dari keseharian warga, mulai dari remaja sampai orang tua sering menggunakan handphone untuk berkomunikasi, termasuk melakukan transaksi jual beli secara online. Kebutuhan warga terhadap komunikasi mobile ini sudah tergolong tinggi, hal ini didukung dengan layanan dari beberapa operator yang melayani masyarakat Ambon untuk berkomunikasi secara mobile. Dari kenyataan ini, terdapat suatu perkecualian yaitu pemanfaatan Facebook belumlah familiar dipakai dalam kegiatan jual-beli online, mereka masih mengutamakan jual- beli dengan tatap-muka langsung dengan penjual maupun menggunakan iklan baris yang tertulis di surat kabar. Jika ternyata ada iklan penjualan melalui Facebook, maka respon/komentar dari netizen yang ditujukan untuk iklan itu pun tidak banyak dan cenderung pasif [4].

Dari data nyata yang sudah disebutkan di atas, yaitu warga kota Ambon sudah familiar menggunakan handphone sejak usia remaja, dan penggunaan handphone ini sudah menjadi suatu tren bagi mereka, namun di sisi lain penggunaan Facebook untuk e-commerce masih rendah, maka jika hal ini dibiarkan dapat dimungkinkan akan terjadi di masa depan tingkat penerimaan masyarakat Ambon menjadi rendah terhadap atas transaksi jual-beli melalui Facebook, dan dapat mengalami kehilangan kesempatan penjualan online melalui Facebook bagi pemasar online, sehingga hal ini dapat mengakibatkan tertinggalnya masyarakat Ambon dibanding dengan wilayah yang lain dalam kegiatan e-commerce melalui Facebook. Berdasarkan permasalahan di atas, peneliti hendak menggali informasi lebih lanjut dari warga kota Ambon yang pernah melakukan e-commerce melalui Facebook. Informasi yang dihimpun dari para responden kemudian dipakai untuk mengetahui pengaruh Facebook terhadap perkembangan $e$ commerce di wilayah Ambon, juga untuk mengetahui alasan warga kota Ambon banyak menggunakan Facebook untuk media transaksi jual-beli secara online, dan untuk mengetahui bagaimana tingkat penerimaan warga kota Ambon terhadap Facebook untuk transaksi e-commerce.

Sehubungan dengan penggunaan Facebook untuk kegiatan e-commerce, maka tujuan yang ingin dicapai melalui penelitian ini adalah untuk mengetahui dan menjelaskan mengenai pengaruh persepsi Kemudahan Penggunaan (Perceive Ease Of Use) terhadap Sikap Penggunaan (Attitude Toward Using), untuk mengetahui dan menjelaskan mengenai pengaruh persepsi Sikap Penggunaan (Attitude Toward Using) terhadap Perilaku Untuk Menggunakan (Behavioral Intention Use), dan untuk mengetahui dan menjelaskan mengenai pengaruh Perilaku Untuk Menggunakan (Behavioral Intention Use) terhadap Kondisi Nyata Penggunaan Sistem (Actual System Usage) Facebook untuk kegiatan e-commerce di kota Ambon.

\section{Metodologi Penelitian}

Jenis penelitian ini merupakan jenis penelitian explanatory (penjelasan) merupakan penelitian yang dilakukan dengann cara menjelaskan mengenai tanggapan pengguna terhadap variabel-variabel yang ditunjukkan pada Tabel I.

TABEL I

Hubungan ANTARA VARIABEL, INDIKATOR, DAN ITEM YANG DIUJI

\begin{tabular}{|c|c|c|}
\hline Variabel & Indikator & Item \\
\hline $\begin{array}{l}\text { Persepsi } \\
\text { Kemudahan } \\
\text { Penggunaan } \\
\text { (Perceived }\end{array}$ & $\begin{array}{l}\text { Facebook } \\
\text { mudah dipelajari }\end{array}$ & $\begin{array}{l}\text { Fitur-fitur yang ada di } \\
\text { Facebook tidak asing } \\
\text { ketika mencobanya } \\
\text { pertama kali }\end{array}$ \\
\hline Ease Of Use) & $\begin{array}{l}\text { Facebook } \\
\text { mudah } \\
\text { digunakan }\end{array}$ & $\begin{array}{l}\text { Kemudahan } \\
\text { mendaftar di } \\
\text { Facebook. }\end{array}$ \\
\hline
\end{tabular}


2. Kemudahan mengunggah foto.

3. Mudah untuk mencari informasi yang diperlukan.

4. Mudah berinteraksi dengan pengguna lain melalui fitur tombol Like.

\begin{tabular}{ll}
\hline Interaksi jelas & Mudah dalam \\
dan mudah & memberikan komentar \\
dipahami & pada foto yang \\
& ditampilkan dan dapat \\
& dengan mudah dibalas \\
& oleh user
\end{tabular}

\begin{tabular}{ll}
\hline Mudah & Mudah mendapatkan \\
beradaptasi & $\begin{array}{l}\text { relasi baru maupun } \\
\text { ide/inspirasi dalam } \\
\text { mengembangkan produk } \\
\text { bisnis }\end{array}$ \\
\hline Keseluruhan & $\begin{array}{l}\text { Secara keseluruhan, } \\
\text { mudah }\end{array}$ \\
instagram mudah \\
digunakan & $\begin{array}{l}\text { melaksanakan dalam } \\
\text { online }\end{array}$ \\
\hline
\end{tabular}

$\begin{array}{ll}\text { Sikap } & \text { Kenyamanan } \\ \text { Penggunaan } & \text { dalam } \\ \text { (Attitude } & \text { berinteraksi }\end{array}$

Toward

Using)

online

Kemudahan dalam melakukan komunikasi dengan pengguna lain dengan memanfaatkan fitur Pesan dan Komentar di Facebook

Senang
menggunakan

Fitur-fitur dan tampilan visual dalam Facebook sangat menarik

\begin{tabular}{|c|c|}
\hline $\begin{array}{l}\text { Menikmati } \\
\text { penggunaan }\end{array}$ & $\begin{array}{l}\text { Tampilan kualitas } \\
\text { visual produk bisnis } \\
\text { menyenangkan karena } \\
\text { dapat dilihat dengan } \\
\text { jelas }\end{array}$ \\
\hline
\end{tabular}

2. Mudah untuk memberikan komentar dalam foto yang ditampilkan

Tidak Tampilan foto yang
membosankan sederhana dan dengan kualitas foto yang baik tidak membuat pusing untuk dilihat

\begin{tabular}{ll}
\hline Perilaku & Memiliki fitur \\
Untuk Tetap & yang membantu \\
Menggunakan & \\
(Behavioral & \\
Intention & \\
Use) &
\end{tabular}

1. Apabila digunakan untuk media bisnis online, Facebook memudahkan untuk pengenalan produk.

2. Fitur-fitur yang ada di Facebook dapat mempermudah pengguna lain untuk membeli produk.
3. Dengan

memanfaatkan

hashtag dapat

memudahkan mencari ataupun mempromosikan produk bisnis.

Selalu mencoba Sekali menggunakan menggunakan Facebook, akan timbul keinginan untuk terus menggunakannya dalam bisnis online

Berlanjut di Fitur-fitur di Facebook masa mendatang dapat dikembangkan lagi untuk kepentingan lain dalam penggunaannya

\begin{tabular}{|c|c|c|}
\hline $\begin{array}{l}\text { Kondisi } \\
\text { Nyata } \\
\text { Penggunaan } \\
\text { Sistem } \\
\text { (Actual } \\
\text { System } \\
\text { Usage) }\end{array}$ & $\begin{array}{l}\text { Frekuensi dan } \\
\text { durasi waktu } \\
\text { penggunaan } \\
\text { terhadap TIK }\end{array}$ & $\begin{array}{l}\text { 1. Apakah hampir setiap } \\
\text { hari membuka } \\
\text { Facebook? } \\
\text { 2. Menghabiskan waktu } \\
\text { berapa menit setiap } \\
\text { kali menggunakan } \\
\text { Facebook? }\end{array}$ \\
\hline & $\begin{array}{l}\text { Penggunaan } \\
\text { teknologi } \\
\text { sesungguhnya } \\
\text { dalam praktek } \\
\text { (actual } \\
\text { technology use) }\end{array}$ & $\begin{array}{l}\text { Facebook merupakan } \\
\text { salah satu bentuk } \\
\text { teknologi canggih dalam } \\
\text { mendukung praktek } \\
\text { bisnis online dengan } \\
\text { memanfaatkan media } \\
\text { sosial }\end{array}$ \\
\hline
\end{tabular}

Peneliti melakukan pendekatan pada penelitian ini dengan cara:

A. Kajian/studi literatur terhadap penelitian-penelitian terdahulu yang berkaitan dengan topik penelitian saat ini, untuk mengetahui sejauh mana hasil penelitian terdahulu sudah berkembang, sehingga penelitian saat ini dapat menghasilkan suatu pengetahuan yang baru.

B. Interview untuk mengetahui apakah responden itu menggunakan Facebook untuk kegiatan e-commerce. Jika responden itu sudah menggunakannya, maka dapat dilanjutkan dengan memberikan kuesioner kepada responden itu.

C. Melalui jawaban di kuesioner dapat dilakukan analisis kuantitatif melalui jawaban-jawaban respondenTiap-tiap jawaban kuesioner memiliki skor/nilai bilangan bulat yang mewakili jawaban yang disediakan, yang meliputi sangat tidak setuju, tidak setuju, netral, setuju, dan sangat setuju dengan menggunakan skala Linkert dengan rentang skore seperti yang tertulis pada Tabel II.

TABEL II

SKALA LINKERT UNTUK NILAI JAWABAN DI KUESIONER

\begin{tabular}{lr}
\hline \multicolumn{1}{c}{ Pilihan Jawaban } & Perolehan Skore \\
\hline Sangat tidak setuju & 1 \\
\hline Tidak setuju & 2 \\
\hline Netral & 3 \\
\hline
\end{tabular}

ISSN: $2337-4055$ 


\begin{tabular}{lr}
\hline Setuju & 4 \\
\hline Sangat setuju & 5 \\
\hline
\end{tabular}

Variabel-variabel yang diteliti pada penelitian ini memiliki pengertian sebagai berikut:

\section{A. Persepsi Kemudahan Penggunaan (Perceived Ease of Use)}

Kemudahan penggunaan (easy of use) yaitu sebagai suatu tingkatan di mana seseorang mempercayai bahwa penggunaan sistem tertentu dapat mengurangi usaha seseorang dalam mengerjakan sesuatu. Intensitas penggunaan dan interaksi antara pengguna (user) dengan sistem dapat menunjukan tingkat kemudahan penggunaan. beberapa indikator kemudahan penggunaan TI antara lain meliputi:

1) Komputer sangat mudah dipelajari,

2) Komputer mengerjakan dengan mudah sesuai yang diinginkan oleh pengguna,

3) Keterampilan pengguna akan bertambah dengan menggunakan komputer, dan

4) Komputer sangat mudah untuk dioperasikan [5].

\section{B. Sikap Terhadap Penggunaan (Attitude Toward Using)}

Sikap terhadap penggunaan sesuatu adalah sikap menyukai atau tidak menyukai terhadap penggunaan suatu produk. Sikap menyukai atau tidak menyukai terhadap suatu produk ini dapat digunakan untuk memprediksi perilaku niat seseorang dalam menggunakan suatu produk atau tidak menggunakannya. Sikap terhadap penggunaan teknologi (attitude toward using technology) didefinisikan sebagai evaluasi dari pemakai tentang ketertarikannya dalam menggunakan teknologi [6].

\section{Minat Perilaku Penggunaan (Behavioral Intention to Use)}

Behavioral intention to use adalah kecenderungan perilaku untuk tetap menggunakan suatu teknologi. Tingkat penggunaan sebuah teknologi komputer pada seseorang dapat diprediksi dari sikap perhatian pengguna terhadap teknologi tersebut, misalkan keinginan menambah peripheral yang mendukung, motivasi untuk tetap menggunakan, dan keinginan untuk memotivasi pengguna lainnya. Minat perilaku menggunakan teknologi (behavioral intention to use) sebagai minat (keinginan) seseorang untuk melakukan perilaku tertentu [7].

\section{Penggunaan Senyatanya (Actual System Usage)}

Penggunaan senyatanya (actual system usage) merupakan kondisi nyata penggunaan sistem. Individu akan puas menggunakan sistem jika meyakini bahwa sistem tersebut mudah digunakan dan dapat meningkatkan produktifitasnya, yang tercermin dari kondisi nyata penggunaan. Bentuk pengukuran penggunaan senyatanya (actual system usage) merupakan frekuensi dan durasi waktu penggunaan terhadap TIK. Penggunaan teknologi sesungguhnya (actual technology use), diukur dengan jumlah waktu yang digunakan untuk berinteraksi dengan teknologi dan frekuensi penggunaan teknologi tersebut [8].

Mengenai jumlah responden dalam penelitian ini, peneliti memakai pendapat Hair dkk (2006) yaitu jumlah sampel bila terlalu besar akan menyulitkan untuk mendapat model yang cocok, dan disarankan ukuran sampel yang sesuai antara 100-
200 responden. Untuk itu jumlah sampel akan ditentukan berdasarkan hasil perhitungan minimum [9].

Langkah-langkah yang dilakukan peneliti dalam analisis data adalah:

A. Membuat suatu Tabel Ketercapaian Skore (Gambar 2) dengan jumlah kolom sesuai jumlah pertanyaan di kuesioner, dan jumlah baris sesuai jumlah responden.

$B$. Untuk tiap-tiap kolom, peneliti mengisikan skore 1 sampai 5 sesuai jawaban yang dipilih responden di nomor pertanyaan yang sesuai. Pilihan skore ini mengikuti ketentuan di Tabel 2. Langkah nomor $(B)$ ini diulangi juga untuk jawaban kuesioner dari responden kedua sampai responden terakhir.

C. Setelah semua kolom dan semua baris berisi skore 1 sampai 5 , peneliti menjumlahkan perolehan skore untuk tiap-tiap kolom di Tabel Ketercapaian Skore. Jumlah perolehan skore dari responden ini diletakkan di bagian bawah Tabel Ketercapaian Skore.

$D$. Jumlah perolehan skore di tiap-tiap kolom dari responden ini kemudian dibagi dengan nilai 150 dan dibagi dengan nilai 100, untuk mengetahui Nilai Ketercapaian dari tiaptiap kolom di Tabel Ketercapaian Skore. Nilai 150 diperoleh dari jumlah responden (30 orang dikalikan dengan nilai 5 (skore maksimal), dan pembagian dengan nilai 100 untuk mengetahui persentase dari Nilai Ketercapaian tiap-tiap kolom di Tabel Ketercapaian Skore.

E. Dari hasil perhitungan di nomor $(D)$, dapat diketahui persentase dari Nilai Ketercapaian tiap-tiap kolom (poinpoin pertanyaan di kuesioner), sehingga dapat mengetahui bagaimana pendapat responden mengenai peran Facebook terhadap e-commerce.

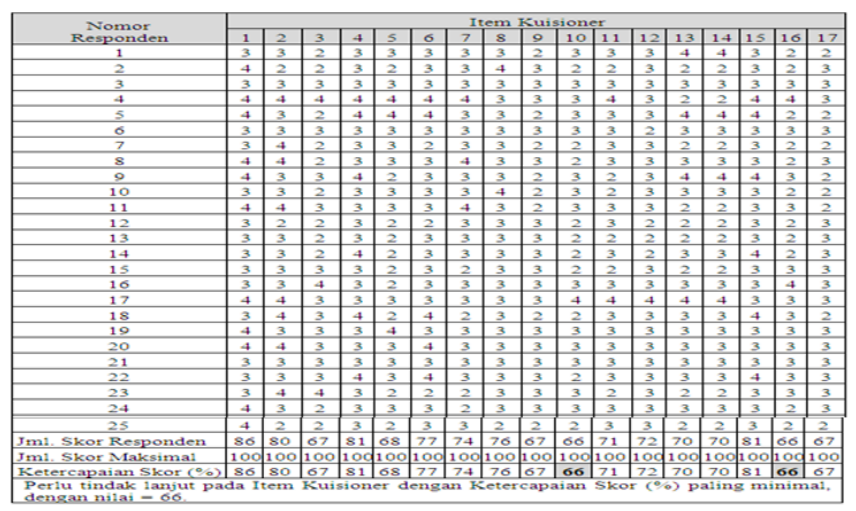

Gambar 2. Rancangan Tabel Ketercapaian Skore.

\section{HASIL DAN PEMBAHASAN}

Tabel III berisi daftar pertanyaan pada kuesioner yang dibagikan kepada responden.

TABEL III

DAFtar PertanyaAn PADA KuEsioner 


\begin{tabular}{|c|c|}
\hline \multirow[t]{2}{*}{ Pertanyaan } & $\begin{array}{c}\text { Pilihan } \\
\text { Jawaban }\end{array}$ \\
\hline & $\overline{\text { STS TS N S SS }}$ \\
\hline \multicolumn{2}{|c|}{$\begin{array}{l}\begin{array}{l}\text { Fitur-fitur di Facebook mudah } \\
\text { dipelajari penggunaannya }\end{array} \\
\end{array}$} \\
\hline \multicolumn{2}{|l|}{$\begin{array}{l}2 \text { Mudah mengunggah foto produk yang } \\
\text { akan dijual }\end{array}$} \\
\hline \multicolumn{2}{|l|}{$\begin{array}{l}3 \text { Mudah untuk mencari informasi } \\
\text { pemilik barang yang akan dijual }\end{array}$} \\
\hline \multicolumn{2}{|l|}{$\begin{array}{l}4 \text { Fitur tombol Like memudahkan } \\
\text { memberi respon dari pengguna lain }\end{array}$} \\
\hline \multicolumn{2}{|l|}{$\begin{array}{l}5 \text { Mudah dalam memberikan komentar } \\
\text { pada foto produk yang ditawarkan dan } \\
\text { dapat dengan mudah dibalas oleh } \text { user }\end{array}$} \\
\hline \multicolumn{2}{|l|}{$\begin{array}{l}6 \text { Dengan banyaknya follower akan } \\
\text { berdampak pada } \\
\text { pengguna lain }\end{array}$} \\
\hline \multicolumn{2}{|l|}{$\begin{array}{l}7 \text { Fitur di Facebook lebih sederhana } \\
\text { dibanding media sosial lain dalam } \\
\text { melakukan interaksi dengan pengguna } \\
\text { lain }\end{array}$} \\
\hline \multicolumn{2}{|l|}{$\begin{array}{l}8 \text { Fitur Pesan dan Komentar di Facebook } \\
\text { memudahkan komunikasi dengan } \\
\text { pengguna lain }\end{array}$} \\
\hline \multicolumn{2}{|l|}{$\begin{array}{l}9 \text { Senang menggunakan Facebook sebab } \\
\text { memiliki fitur-fitur dan tampilan visual } \\
\text { sangat menarik }\end{array}$} \\
\hline \multicolumn{2}{|l|}{$\begin{array}{l}10 \text { Dapat menikmati penggunaan } \\
\text { Facebook karena tampilan kualitas } \\
\text { visual produk bisnis dapat dilihat } \\
\text { dengan jelas }\end{array}$} \\
\hline \multicolumn{2}{|l|}{$\begin{array}{l}11 \text { Saya menikmati penggunaan Facebook } \\
\text { karena mudah memberikan komentar } \\
\text { untuk foto produk yang ditampilkan }\end{array}$} \\
\hline \multicolumn{2}{|l|}{$\begin{array}{l}12 \text { Facebook memudahkan untuk } \\
\text { memperkenalkan produk dalam bisnis } \\
\text { online. }\end{array}$} \\
\hline \multicolumn{2}{|l|}{$\begin{array}{l}\text { 13 Facebook memudahkan calon pembeli } \\
\text { untuk membeli produk yang } \\
\text { ditawarkan. }\end{array}$} \\
\hline \multicolumn{2}{|l|}{$\begin{array}{l}\text { 14 Fitur hashtag dapat memudahkan } \\
\text { mencari ataupun mempromosikan } \\
\text { produk bisnis }\end{array}$} \\
\hline \multicolumn{2}{|l|}{$\begin{array}{l}\text { 15 Sekali menggunakan Facebook, akan } \\
\text { timbul keinginan untuk terus } \\
\text { menggunakannya dalam bisnis online }\end{array}$} \\
\hline \multicolumn{2}{|l|}{$\begin{array}{l}16 \text { Fitur-fitur di Facebook dapat } \\
\text { dikembangkan lagi untuk kepentingan } \\
\text { lain dalam penggunaannya }\end{array}$} \\
\hline \multicolumn{2}{|l|}{$\begin{array}{l}17 \text { Facebook dapat mendukung praktek } \\
\text { bisnis online }\end{array}$} \\
\hline $\begin{array}{l}18 \text { Saya setiap hari membuka Facebook } \\
\text { maksimal } 1 \text { jam }\end{array}$ & \\
\hline
\end{tabular}

Data rekap hasil penilaian jawaban kuesioner untuk 30 orang responden ditunjukkan melalui data pada Tabel IV.

TABEL IV

\section{REKAPITULASI JAWABAN KUESIONER}

\section{Perolehan Nilai untuk Setiap Pertanyaan}

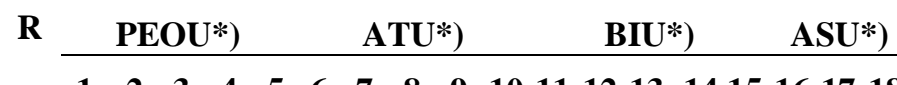

$\begin{array}{llllllllllllllllll}1 & 2 & 3 & 4 & 5 & 6 & 7 & 8 & 9 & 10 & 11 & 12 & 13 & 14 & 15 & 16 & 17 & 18\end{array}$

\begin{tabular}{lllllllllllllllllll}
\hline 1 & 4 & 4 & 4 & 4 & 4 & 4 & 4 & 4 & 5 & 5 & 4 & 4 & 4 & 4 & 4 & 4 & 4 & 3
\end{tabular}

\begin{tabular}{lllllllllllllllllll}
2 & 4 & 4 & 3 & 5 & 5 & 5 & 4 & 5 & 4 & 5 & 4 & 4 & 4 & 5 & 3 & 4 & 3 & 3 \\
\hline
\end{tabular}

$\begin{array}{lllllllllllllllllll}3 & 4 & 4 & 4 & 5 & 4 & 5 & 3 & 4 & 3 & 4 & 4 & 5 & 4 & 4 & 4 & 4 & 5 & 1\end{array}$

$\begin{array}{lllllllllllllllllll}4 & 4 & 4 & 4 & 4 & 4 & 4 & 4 & 4 & 4 & 4 & 4 & 4 & 4 & 4 & 4 & 4 & 4 & 1\end{array}$

\begin{tabular}{lllllllllllllllllll}
5 & 5 & 5 & 4 & 5 & 4 & 3 & 4 & 4 & 5 & 4 & 5 & 4 & 3 & 3 & 3 & 4 & 4 & 3 \\
\hline
\end{tabular}

\begin{tabular}{lllllllllllllllllll}
6 & 5 & 4 & 2 & 5 & 4 & 5 & 3 & 3 & 3 & 3 & 3 & 4 & 4 & 4 & 1 & 5 & 4 & 2 \\
\hline
\end{tabular}

\begin{tabular}{lllllllllllllllllll}
7 & 5 & 5 & 2 & 4 & 4 & 4 & 4 & 5 & 4 & 4 & 4 & 5 & 4 & 4 & 4 & 5 & 4 & 5 \\
\hline
\end{tabular}

\begin{tabular}{llllllllllllllllllll}
8 & 4 & 5 & 4 & 3 & 4 & 3 & 5 & 4 & 4 & 4 & 4 & 4 & 4 & 4 & 4 & 4 & 5 & 3 \\
\hline
\end{tabular}

$\begin{array}{lllllllllllllllllll}9 & 5 & 5 & 3 & 5 & 5 & 3 & 5 & 5 & 4 & 4 & 4 & 5 & 4 & 4 & 4 & 4 & 5 & 5\end{array}$

\begin{tabular}{lllllllllllllllllll}
10 & 4 & 4 & 4 & 4 & 4 & 4 & 4 & 4 & 4 & 4 & 4 & 4 & 4 & 4 & 4 & 4 & 4 & 4 \\
\hline
\end{tabular}

\begin{tabular}{lllllllllllllllllll}
11 & 4 & 4 & 3 & 5 & 5 & 5 & 4 & 5 & 4 & 5 & 4 & 4 & 4 & 5 & 3 & 4 & 3 & 3 \\
\hline
\end{tabular}

\begin{tabular}{lllllllllllllllllll}
12 & 4 & 4 & 4 & 4 & 4 & 4 & 4 & 4 & 4 & 4 & 4 & 4 & 4 & 4 & 4 & 4 & 4 & 1 \\
\hline
\end{tabular}

\begin{tabular}{lllllllllllllllllll}
13 & 5 & 4 & 2 & 5 & 4 & 5 & 3 & 3 & 3 & 3 & 3 & 4 & 4 & 4 & 1 & 5 & 4 & 2 \\
\hline
\end{tabular}

\begin{tabular}{lllllllllllllllllll}
14 & 4 & 5 & 4 & 3 & 4 & 3 & 5 & 4 & 4 & 4 & 4 & 4 & 4 & 4 & 4 & 4 & 5 & 3 \\
\hline
\end{tabular}

$\begin{array}{lllllllllllllllllll}15 & 4 & 4 & 4 & 4 & 4 & 4 & 4 & 4 & 4 & 4 & 4 & 4 & 4 & 4 & 4 & 4 & 4 & 4\end{array}$

\begin{tabular}{lllllllllllllllllll}
16 & 4 & 4 & 4 & 4 & 4 & 4 & 4 & 4 & 5 & 5 & 4 & 4 & 4 & 4 & 4 & 4 & 4 & 3 \\
\hline
\end{tabular}

\begin{tabular}{lllllllllllllllllll}
17 & 4 & 4 & 4 & 5 & 4 & 5 & 3 & 4 & 3 & 4 & 4 & 5 & 4 & 4 & 4 & 4 & 5 & 1 \\
\hline
\end{tabular}

\begin{tabular}{lllllllllllllllllll}
18 & 5 & 5 & 4 & 5 & 4 & 3 & 4 & 4 & 5 & 4 & 5 & 4 & 3 & 3 & 3 & 4 & 4 & 3 \\
\hline
\end{tabular}

\begin{tabular}{lllllllllllllllllll}
19 & 5 & 5 & 2 & 4 & 4 & 4 & 4 & 5 & 4 & 4 & 4 & 5 & 4 & 4 & 4 & 5 & 4 & 5 \\
\hline
\end{tabular}

$\begin{array}{lllllllllllllllllll}20 & 5 & 5 & 3 & 5 & 5 & 3 & 5 & 5 & 4 & 4 & 4 & 5 & 4 & 4 & 4 & 4 & 5 & 5\end{array}$

\begin{tabular}{lllllllllllllllllll}
21 & 4 & 4 & 4 & 5 & 4 & 5 & 3 & 4 & 3 & 4 & 4 & 5 & 4 & 4 & 4 & 4 & 5 & 1 \\
\hline
\end{tabular}

\begin{tabular}{lllllllllllllllllll}
22 & 5 & 4 & 2 & 5 & 4 & 5 & 3 & 3 & 3 & 3 & 3 & 4 & 4 & 4 & 1 & 5 & 4 & 2 \\
\hline
\end{tabular}

\begin{tabular}{lllllllllllllllllll}
23 & 5 & 5 & 3 & 5 & 5 & 3 & 5 & 5 & 4 & 4 & 4 & 5 & 4 & 4 & 4 & 4 & 5 & 5 \\
\hline
\end{tabular}

\begin{tabular}{lllllllllllllllllll}
24 & 4 & 4 & 4 & 4 & 4 & 4 & 4 & 4 & 5 & 5 & 4 & 4 & 4 & 4 & 4 & 4 & 4 & 3 \\
\hline
\end{tabular}

\begin{tabular}{lllllllllllllllllll}
25 & 4 & 4 & 4 & 4 & 4 & 4 & 4 & 4 & 4 & 4 & 4 & 4 & 4 & 4 & 4 & 4 & 4 & 1 \\
\hline
\end{tabular}

\begin{tabular}{lllllllllllllllllll}
26 & 5 & 5 & 2 & 4 & 4 & 4 & 4 & 5 & 4 & 4 & 4 & 5 & 4 & 4 & 4 & 5 & 4 & 5 \\
\hline
\end{tabular}

\begin{tabular}{lllllllllllllllllll}
27 & 4 & 4 & 3 & 5 & 5 & 5 & 4 & 5 & 4 & 5 & 4 & 4 & 4 & 5 & 3 & 4 & 3 & 3 \\
\hline
\end{tabular}

\begin{tabular}{lllllllllllllllllll}
28 & 5 & 5 & 4 & 5 & 4 & 3 & 4 & 4 & 5 & 4 & 5 & 4 & 3 & 3 & 3 & 4 & 4 & 3 \\
\hline
\end{tabular}

\begin{tabular}{lllllllllllllllllll}
29 & 4 & 5 & 4 & 3 & 4 & 3 & 5 & 4 & 4 & 4 & 4 & 4 & 4 & 4 & 4 & 4 & 5 & 3 \\
\hline
\end{tabular}

$\begin{array}{lllllllllllllllllll}30 & 4 & 4 & 4 & 4 & 4 & 4 & 4 & 4 & 4 & 4 & 4 & 4 & 4 & 4 & 4 & 4 & 4 & 4\end{array}$

*) $\mathrm{R}=$ Responden. PEOU $=$ Perceived Easy of Use. ATU = Attitude Toward Using. BIU = Behavioral Intention Use. ASU = Actual System Usage.

Berdasarkan data skore jawaban kuesioner pada Tabel IV dapat diperoleh beberapa hasil perhitungan seperti yang ditulis pada Tabel V di bawah ini.

TABEL V 
DATA HASIL PERHITUNGan KeTERCAPAIAN SKorE pengguna lain, dan Mudah dalam memberikan komentar pada foto produk yang ditawarkan dan dapat dengan BIU mudah dibstas oleh user.

PEOU ATU

2) Grup varrabel-Sikap Penggunaan (Attitude Toward

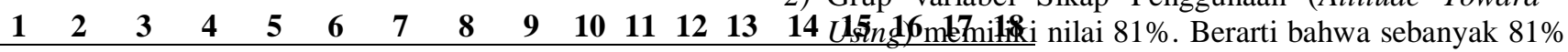
TSR $132132 \quad 102 \quad 132 \quad 126 \quad 120120126 \quad 120123120129117 \quad 120$ resBq2\&emp6mempercayai respon follower mengenai $\begin{array}{lllllllllllllll}\text { TSR } 132 & 132 & 102 & 132 & 126 & 120 & 120 & 126 & 120 & 123120129 & 117 & 120 & \text { kepercayaan pengguna lain, responden merasakan }\end{array}$

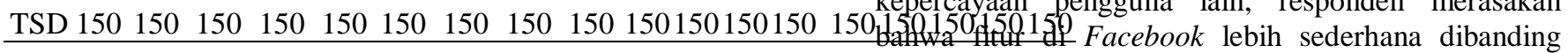

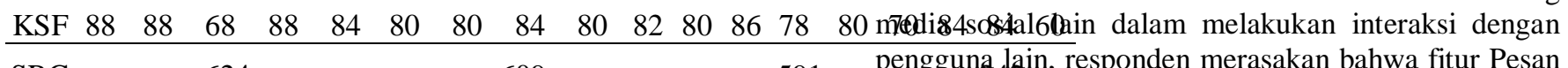

\begin{tabular}{|c|c|c|c|c|}
\hline SRG & 624 & 609 & 591 & $\begin{array}{l}\text { penggunąlain, responden merasakan bahwa fitur Pesan } \\
\text { dan Komentar di Facebook memudahkan komunikasi }\end{array}$ \\
\hline
\end{tabular}

Avg1 $125 \quad 122 \quad 118 \quad$\begin{tabular}{l} 
dengan plehtgguna lain, responden senang menggunakan \\
\hline
\end{tabular}

\begin{tabular}{llll}
\hline SDG & 750 & 750 & Facebook5f5bab memiliki fitur-fitur dan tampilan visual
\end{tabular}

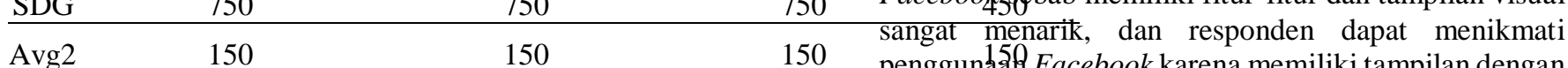

$\begin{array}{llll}\text { Avg2 } & 150 & 150 & \text { penggund } 150 \text { Facebook karena memiliki tampilan dengan }\end{array}$

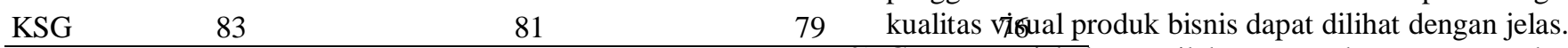

Penulis menjelaskan beberapa singkatan pada Tabel V sebagai berikut:

A. TSR $=$ Total Skore Responden untuk setiap pertanyaan,

B. TSD = Total Skore Diharapkan,

C. $\mathrm{KSF}=$ Ketercapaian Skore Fitur pada Facebook,

D. $\mathrm{SRG}=$ Total Skore Responden untuk setiap Grup Variabel,

E. Avg1 = Rata-rata Skore Responden untuk setiap Grup Variabel,

F. $\mathrm{SDG}=$ Total Skore Diharapkan untuk setiap Grup Variabel,

G. Avg2 = Rata-rata Skore Diharapkan untuk setiap Grup Variabel, dan

H. $\mathrm{KSG}=$ Ketercapaian Skore Fitur pada Facebook untuk setiap Grup Variabel.

Berdasarkan data pada Tabel 6 dapat dijelaskan beberapa hal di bawah ini:

A. Nilai terendah dari KSF adalah untuk poin-poin pertanyaan pada dua nomor di bawah ini, yaitu:

1) Pertanyaan nomor 3, hal ini memiliki arti bahwa para responden tidak mudah untuk mencari informasi pemilik barang yang akan dijual. Untuk itu dapat direkomendasikan bahwa informasi pemilik barang dapat dibuat selengkap mungkin dan dimasukkan melalui interface khusus untuk menyimpan data pemilik barang.

2) Pertanyaan nomor 18 , hal ini memiliki arti bahwa para responden setiap hari membuka Facebook kurang 1 jam. Untuk itu dapat direkomendasikan bahwa sistem Facebook perlu diperbaiki dengan menambahkan kemudahan-kemudahan yang lain agar menarik perhatian responden agar bersedia membuka Facebook minimal 1 jam per hari.

B. Dari nilai KSG diperoleh:

1) Grup variabel Persepsi Kemudahan Penggunaan (Perceived Ease Of Use) memiliki nilai 83\%. Artinya sebanyak $83 \%$ responden merasakan kemudahan di dalam menggunakan Facebook untuk mempelajari fiturfitur Facebook, mudah mengunggah foto produk yang akan dijual, pemilik barang mudah ditemukan, fitur tombol Like memudahkan memberi respon dari
3) Grup variabel Perilaku Untuk Menggunakan (Behavioral Intention Use) memiliki nilai 79\%, yang berarti bahwa sebanyak $79 \%$ responden dapat menikmati penggunaan Facebook karena mudah memberikan komentar untuk foto produk yang ditampilkan, responden merasa dimudahkan untuk memperkenalkan produk dan merasa dimudahkan untuk membeli produk yang ditawarkan, dan $79 \%$ responden itu memiliki keinginan untuk terus menggunakan Facebook dalam bisnis online.

4) Grup variabel Kondisi Nyata Penggunaan Sistem (Actual System Usage) memiliki nilai 76\%. Hal ini memiliki arti bahwa $76 \%$ responden mengharapkan fitur-fitur di Facebook dapat dikembangkan lagi untuk kepentingan lain dalam penggunaannya, mereka menyatakan bahwa Facebook dapat mendukung praktek bisnis online, dan mereka setiap hari membuka Facebook maksimal 1 jam.

\section{KESIMPULAN}

Penulis dapat memberikan beberapa kesimpulan sebagai berikut:

A. Variabel persepsi Kemudahan Penggunaan (Perceived Ease Of Use) memiliki pengaruh signifikan positif terhadap Sikap Penggunaan (Attitude Toward Using), dengan nilai sebesar $83 \%$ berbanding $81 \%$.

B. Variabel Sikap Penggunaan (Attitude Toward Using) memiliki pengaruh signifikan positif terhadap Perilaku Untuk Menggunakan (Behavioral Intention Use), dengan nilai sebesar $81 \%$ berbanding $79 \%$.

C. Variabel Perilaku Untuk Menggunakan (Behavioral Intention Use) memiliki pengaruh signifikan positif terhadap Kondisi Nyata Penggunaan Sistem (Actual System Usage), dengan nilai sebesar $79 \%$ berbanding $76 \%$.

\section{UCAPAN TERIMA KASIH}

Pada kesempatan ini penulis mengucapkan banyak terima kasih kepada para pihak yang turut andil sehingga studi penulis dapat terselesaikan. Ucapan terima kasih penulis tujukan kepada yang terhormat:

A. Dr. Prihandoko, M.IT. selaku Direktur Program S2 PJJ Konsorsium APTIKOM-AMIKOM, atas segala 
kebijaksanaan, perhatian, dan dorongan sehingga penulis dapat menyelesaikan studi S2 Teknik Informatika ini.

B. Prof. Dr. M. Suyanto, M.M. selaku Rektor Universitas AMIKOM Yogyakarta.

C. Dr. Kusrini, M.Kom. selaku Direktur Pascasarjana Universitas AMIKOM Yogyakarta.

D. Dr. Lana Sularto, S.E., M.MSi. selaku Dosen Pembimbing dalam penelitian ini yang telah banyak memberikan pengarahan, bimbingan, dan memberi motivasi sampai penelitian selesai tersusun.

E. Bapak dan ibu dosen PJJ APTIKOM-AMIKOM dan Admisi Program Pascasarjana Universitas AMIKOM Yogyakarta yang telah memberikan bekal ilmu dan pelayanan yang sangat bermanfaat.

F. Pengurus Lembaga Penelitian dan Pengabdian kepada Masyarakat Sekolah Tinggi Teknologi Indonesia, Tanjungpinang, Kepulauan Riau, yang telah bersedia mempublikasikan hasil penelitian ini.

G. Rekan-rekan di program studi Magister Teknik Informatika PJJ Konsorsium APTIKOM-AMIKOM angkatan IV khususnya dan semua rekan mahasiswa Program Pascasarjana Universitas AMIKOM Yogyakarta, yang telah memberikan dukungan moral dan semangat untuk segera menyelesaikan studi.

\section{REFERENSI}

[1] (2017) Statista website. [Online]. Leading countries based on number of Facebook users as of July 2017 (in millions).

Available: http://academia.edu/xpl/freeabs_all.jsp?arnumber=54172 67, diakses tanggal 28 November 2018.

[2] (2019) databoks.katadata.co.id website. [Online]. Available:

https://databoks.katadata.co.id/datapublish/2019/04/01/fa cebook-media-sosial-yang-paling-banyak-digunakanuntuk-e-commerce, diakses tanggal 5 Juli 2019.
[3] (2019) Website Kilas Maluku.com. [Online]. Badan Pusat Statistik Kota Ambon. Data Demografi Kota Ambon. Available: https://prezi.com/onzli60uf6lh/datademografi-kota-ambon/, diakses tanggal 5 Juli 2019.

[4] (2019) Website Kilas Maluku.com. [Online]. Harian Kabar Timur, Pola Konsumsi Internet Warga Ambon, https://prezi.com/onzli71 vg7mi/pola-konsumsi-internetwarga-ambon/, diakses tanggal 5 Juli 2019.

[5] Flourensia Sapty Rahayu, Djoko Budiyanto, and David Palyama, "Analisis Penerimaan e-Learning Menggunakan Technology Acceptance Model (TAM) Studi Kasus: Universitas Atma Jaya Yogyakarta", JUTEI, Vol. 1 No. 2, Oktober 2017.

[6] Fran Sayekti and Pulasna Putarta, "Penerapan Technology Acceptance Model (TAM) dalam Pengujian Model Penerimaan Sistem Informasi Keuangan Daerah", Jurnal Manajemen Teori dan Terapan, Tahun 9, No. 3, Desember 2016.

[7] Prasetyo, "Evaluasi Penerimaan e-Library sebagai Sistem Otomasi Perpustakaan menggunakan Technology Acceptance Model (TAM) Berdasarkan Persepsi Pustakawan di Perpustakaan Universitas Muhammadiyah Yogyakarta", Skripsi, Fakultas Adab dan Ilmu Budaya, Universitas Islam Negeri Sunan Kalijaga, Yogyakarta, 2017.

[8] Nanang Hunaifi, "Penerapan Metode TAM terhadap Penerimaan Sistem Informasi Produksi Garment", Jurnal Informatika, Vol. 5 No. 2, September 2018.

[9] Prasetyo, "Evaluasi Penerimaan e-Library sebagai Sistem Otomasi Perpustakaan menggunakan Technology Acceptance Model (TAM) Berdasarkan Persepsi Pustakawan di Perpustakaan Universitas Muhammadiyah Yogyakarta", Skripsi, Fakultas Adab dan Ilmu Budaya, Universitas Islam Negeri Sunan Kalijaga, Yogyakarta, 2017. 